\title{
Silurian crinoids of the New Brunswick Museum, Saint John, Canada
}

\author{
Stephen K. DonOvan ${ }^{1,3^{*}}$ And Randall F. MilleR ${ }^{2,3}$ \\ 1. Taxonomy and Systematics Group, Naturalis Biodiversity Center, Postbus 9517, \\ 2300 RA Leiden, The Netherlands \\ 2. Steinhammer Palaeontology Laboratory, Natural Science Department, New Brunswick Museum, \\ Saint John, New Brunswick E2K 1E5, Canada \\ 3. Department of Earth Sciences, University of New Brunswick, Fredericton, New Brunswick E3B 5A3, Canada \\ *Corresponding author <steve.donovan@naturalis.nl>
}

Date received: 12 May 2016 gate accepted: 11 August 2016

\begin{abstract}
The New Brunswick Museum's collection of Silurian crinoids from eastern Canada is small, and includes specimens from New Brunswick, Quebec and Nova Scotia. Material considered herein is, with one exception, from New Brunswick. Included are: the cladid Syndetocrinus dartae (Upper Silurian of Quebec); the camerates Scyphocrinites sp. (Pridoli or Lochkovian) and camerate crinoid arms gen. et sp. indet. (Lower Silurian); columnal morphotaxa Floricrinus (col.) sp. (Ludlow or Pridoli) and Lanxocolumnus (col.) sp. cf. L. chaleurensis Donovan and Keighley (probably Llandovery, Telychian); distal dendritic radicular attachments (Ludlow or Pridoli); and disarticulated brachials (Ludlow or Pridoli). The fossil record of crinoids from the Silurian of New Brunswick appears depauperate, but this most likely reflects the poor preservation of the specimens (commonly disarticulated and moldic) and the lack of interest shown by collectors. The only remedy for this problem would be either discovery of a crinoid Lagerstätte, which would be attractive to collectors, or a focused campaign of collecting of disarticulated material from multiple outcrops.
\end{abstract}

\begin{abstract}
RÉSUMÉ
La collection de crinoïdes siluriens de l'est du Canada du Musée du Nouveau-Brunswick est petite et composée de spécimens du Nouveau-Brunswick, du Québec et de la Nouvelle-Écosse. À une seule exception, les pièces dont il est question ici proviennent du Nouveau-Brunswick. Elles comprennent Syndetocrinus dartae de l'ordre des Cladida (Silurien supérieur du Québec); Scyphocrinites sp. de l’ordre des Camerata (Pridolien ou Lochkovien) et des bras de crinoïdes Camerata, gen. et sp. indet. (Silurien inférieur); morphotaxons de columnales à Floricrinus (col.) sp. (Ludlovien ou Pridolien) et Lanxocolumnus (col.) sp. cf. L. chaleurensis Donovan et Keighley (probablement Llandovérien, Télychien); racines distales de forme dendritique (Ludlovien ou Pridolien); brachiales désarticulées (Ludlovien ou Pridolien). La chronique de fossiles de crinoïdes du Silurien du Nouveau-Brunswick semble défectueuse, ce qui témoigne probablement de la préservation inadéquate des spécimens (généralement désarticulés et moisis) et du manque d'intérêt manifesté par les collectionneurs. La seule chose qui pourrait remédier à ce problème serait la découverte d'un Lagerstätte à crinoïdes, ce qui serait attrayant pour les collectionneurs, ou une campagne ciblée de collecte de matériel désarticulé provenant de multiples affleurements rocheux.
\end{abstract}

[Traduit par la redaction] 


\section{INTRODUCTION}

The Silurian to Devonian interval links the two great 'ages' of crinoids in the Paleozoic. The Ordovician was the first great age of crinoids, when the group was first evolving in the niches that it would fill for much of the Paleozoic (Guensburg and Sprinkle 2003; Guensburg 2010). Crinoids flourished and diversified during the Ordovician in three major groups - disparids, cladids and camerates - until severely reduced in diversity by the end-Ordovician mass extinction (Eckert 1988; Donovan 1988, 1994; Brenchley 1989; Ausich and Deline 2012). About twelve families and many genera failed to survive into the Silurian. Although crinoids may have been even more speciose in parts of the Silurian-Devonian than during the Ordovician (Hess and Ausich 1999, fig. 3), they had lost much of the diversity of form displayed during their early radiation. Nevertheless, the Silurian is distinguished by its own distinctive crinoid taxa (e.g., Donovan et al. 2009, 2010, 2012a), many of which persisted into the Devonian. The Late Devonian (Frasnian/Famennian) mass extinction was not as noticeably detrimental to the crinoids as that at the end of the Ordovician, and the survivors evolved and diversified in the Mississippian, the great 'Age of Crinoids', most recently reanalyzed by Kammer and Ausich (2006).

The interest in the Silurian Crinoidea is thus not just in its own diversity, but also how it demonstrates recovery from the end-Ordovician mass extinction and evolution before the Mississippian 'Age of Crinoids'. The Silurian crinoid radiation, following the end-Ordovician extinction event, has now been well documented in Llandovery strata from Iowa and Ohio in the midwestern United States, through New York, into Ontario and Anticosti Island (Quebec) in Canada, and across to the British Isles (Donovan 1994; Ausich and Copper 2010; Ausich and Deline 2012; Donovan and Keighley 2015). The Silurian strata around the coast of southern mainland Quebec and New Brunswick constitute one of the remaining gaps in the dataset. The Silurian crinoids of this region form part of the paleogeographic 'link' between Laurentia and Avalonia, yet remain largely unknown and understudied.

New Brunswick has extensive outcrops and locally good exposures of fossiliferous, marine, Silurian sedimentary rocks (Fig. 1), but the crinoids of this succession remain poorlyknown. Recently, Donovan and Miller (2014) reported Scyphocrinites sp. from west of Campbellton, northern New Brunswick, a widely distributed genus that spans the Silurian-Devonian transition. Donovan and Keighley (2015) described a distinctive crinoid columnal morphospecies, Lanxocolumnus (col.) chaleurensis, from a coastal exposure at Quinn Point, about $7 \mathrm{~km}$ west of Belledune, northern New Brunswick, in vertically bedded limestones of the Limestone Point Formation, Quinn Point Group (Llandovery, Telychian); see also Donovan et al. (2015) (Fig. 1E). Herein, we examine the largest collection of Silurian crinoids from
New Brunswick, that of the New Brunswick Museum in Saint John, and add more diversity to the understudied Silurian crinoids of the province by reference to historic collections that have been largely ignored until now.

\section{SYSTEMATIC PALAEONTOLOGY}

Further to the Silurian taxa recorded below, the NBMG collections include a 20 -armed monobathrid camerate gen. et sp. indet. from the Ludlow of Nova Scotia (Donovan and Pickerill 1995) (Fig. 1F) and three nominal crinoid morphospecies from the Upper Silurian of Quebec (Donovan and Keighley 2016). Donovan and Miller (2014) already described Scyphocrinites sp., but it is included here for completeness of the taxa from New Brunswick.

Terminology for the crinoid endoskeleton follows Moore et al. (1968, 1978a), Ubaghs (1978a), Brett (1981) and Webster (1974). Our philosophy of open nomenclature follows Bengtson (1988). The specimens illustrated and described herein are deposited in the geological collections of the New Brunswick Museum, Saint John (NBMG).

Class Crinoidea J.S. Miller 1821

Subclass Camerata Wachsmuth and Springer 1885

Order Monobathrida Moore and Laudon 1943

Family Scyphocrinitidae Jaekel 1918

Genus Scyphocrinites Zenker 1833

TYPE SPECIES: Scyphocrinites elegans Zenker 1833, p. 25, by monotypy (Ubaghs 1978b, p. T489).

DIAGNOSIS: See Ubaghs (1978b, p. T489).

REMARKS: See Donovan and Miller (2014).

RANGE: Upper Silurian (Pridoli) to Lower Devonian (lowermost Lochkovian), global in distribution (Haude 1992); Lower? Silurian, 'Middle' (Upper?) Silurian to Lower Devonian, cosmopolitan (Webster and Webster 2014,p.1994).

\section{Scyphocrinites sp.}

(Figure 2)

MATERIAL: A single specimen, NBMG 16862 (Fig. 2).

LOCALITY AND HORIZON: Flatlands, New Brunswick. Indian Point Formation, either Pridoli (Upper Silurian) or lower to middle Lochkovian (Lower Devonian) (Fig. 1A).

DESCRIPTION: See Donovan and Miller (2014, p. 295). 


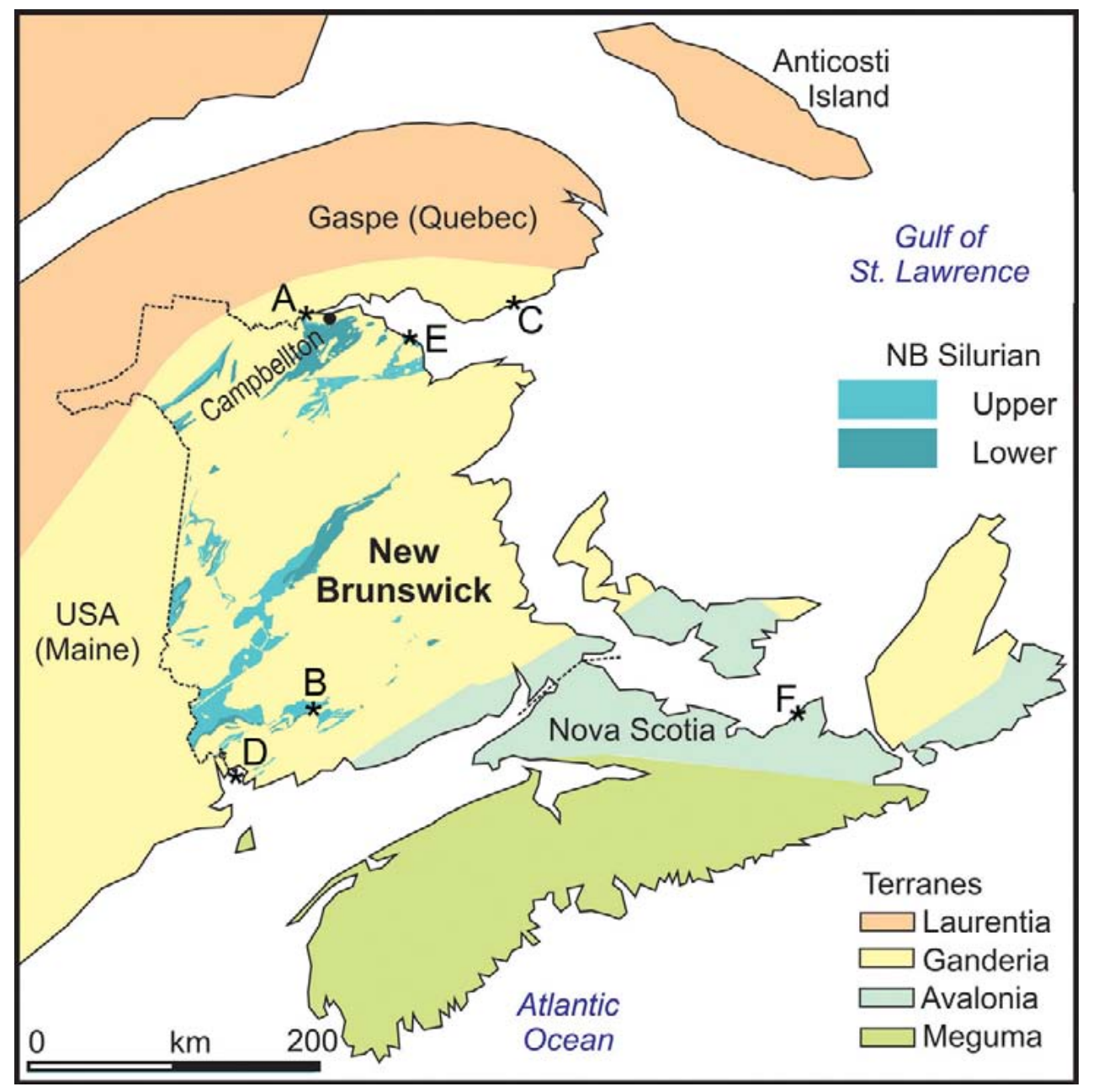

Figure 1. General location map of New Brunswick, eastern Canada, and adjacent territories, showing the geometry of the principal terranes and the Silurian outcrop (modified after Donovan and Keighley 2015, fig. 1A). Key to localities: $\mathrm{A}=$ Flatlands, Indian Point Formation, Pridoli or Lochkovian (Scyphocrinites sp.); B = Nerepis, Jones Creek Formation, Lower Silurian (camerate crinoid arms gen. et sp. indet., Lanxocolumnus (col.) sp. cf. L. chaleurensis Donovan and Keighley); C $=$ Port Daniel, West Point Formation, Upper Silurian (Syndetocrinus dartae Kirk); D = Cookson Island, Upper Silurian (Floricrinus (col.) sp., distal dendritic radicular attachment, brachials); E = near Belledune, Limestone Point Formation, Quinn Point Group, Telychian (Lanxocolumnus (col.) chaleurensis); F = Donovan and Pickerill (1995) location, Moydart Formation, Ludlow (monobathrid camerate gen. et sp. indet.). Figure modified and improved by David G. Keighley.

REMARKS: This taxon was examined in detail by Donovan and Miller (2014). Because of its unusual morphology as a flotation aid for a planktonic crinoid (Haude 1992), we consider it worthy of refiguring (Fig. 2), alerting other geologists that this is a marker for the Silurian/Devonian boundary worldwide.

\section{Camerata incerti ordinis}

camerate crinoid arms gen. et sp. indet.

(Figures 3A, B)

\section{MATERIAL: NBMG 2413/11.}

LOCALITY AND HORIZON: "McIntyre's, Nerepis, New Brunswick, Silurian" (specimen label); Jones CreekFormation, Mascarene Group, Lower Silurian (MacKenzie 1964) (Fig. 1B).

DESCRIPTION: Five long, unbranched arms, biserial, with long, slender pinnules (Figs. 3A, B). Four of the branches are closely associated and may represent one arm which had branched twice isotomously.

REMARKS: This specimen was probably derived from a camerate crinoid, indicated by the biseriality of the arms and pinnulation. 


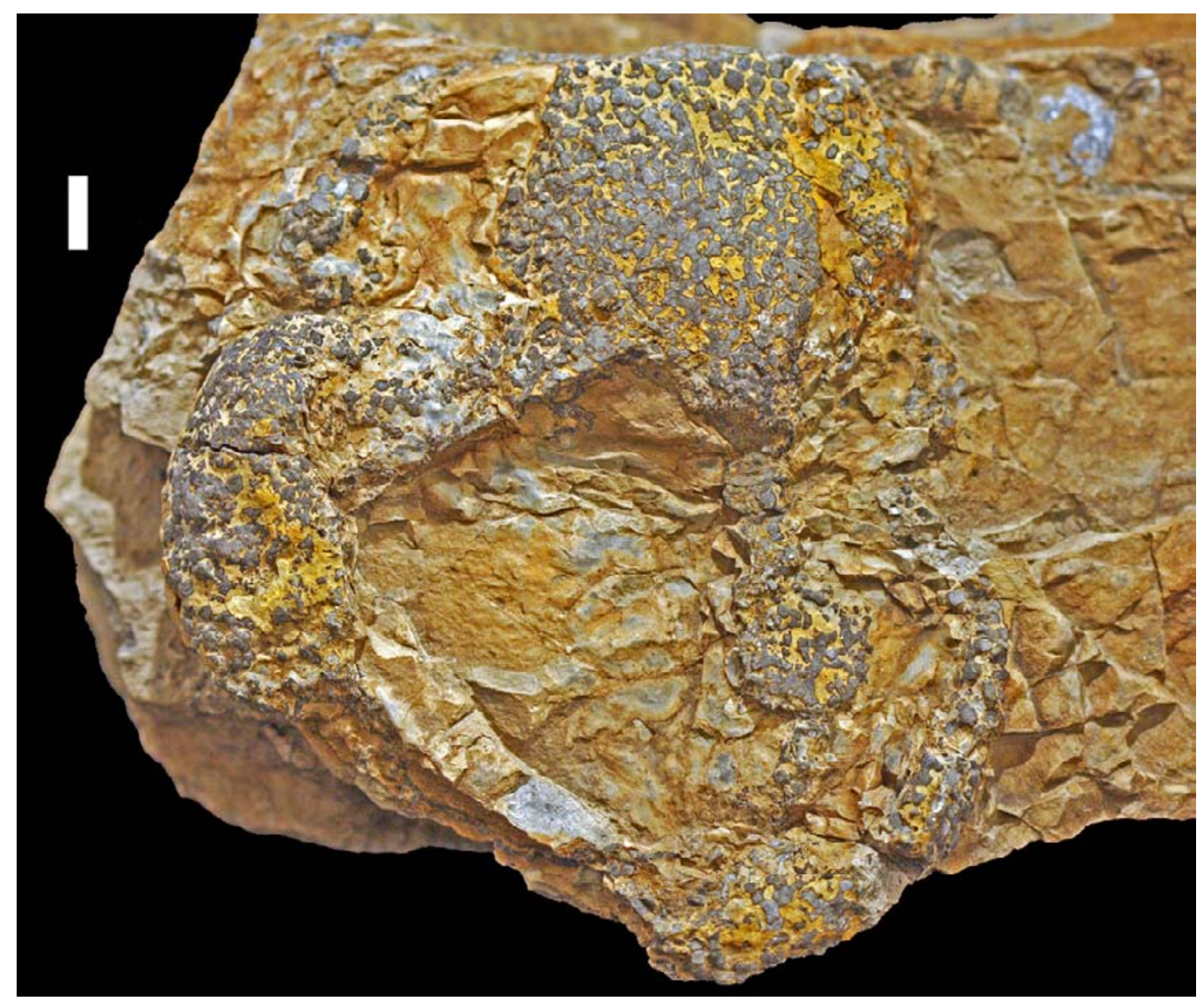

Figure 2. NBMG 16862, Scyphocrinites sp., a collapsed lobolith from the Indian Point Formation, northern New Brunswick (after Donovan and Miller 2014, fig. 4); Upper Silurian (Pridoli) or, less likely, Lower Devonian (Lochkovian). Specimen uncoated. Scale bar represents $10 \mathrm{~mm}$.

\section{Subclass Cladida Moore and Laudon 1943 \\ Family Crotalocrinitidae Bassler 1938 \\ Genus Syndetocrinus Kirk 1933}

TYPE SPECIES: Syndetocrinus dartae Kirk 1933, p. 345, by original designation, from the Upper Silurian West Point Formation of Port Daniel, Quebec.

DIAGNOSIS: (Modified after Moore et al. 1978b, p. T594.) Cup low, with wide flat base and straight or gently convex sides; infrabasals low, mostly covered by wide proximal columnal; radials wide, low, separated on posterior side by pentagonal anal X; CD basal truncate above for contact with anal $\mathrm{X}$ or separated from it by edges of $\mathrm{C}$ and $\mathrm{D}$ radials; axial canal present in radials and brachials. Tegmen low, composed of numerous small irregular plates; orals not certainly identified. Arms with axillary primibrachials $\mathrm{IBr}_{1}$ occupying one-half to full width of radial; where primaxillary is narrow, $\mathrm{IIBr}_{1}$ in contact with lateral edge of radial; $\mathrm{IIBr}_{2}$ and $I I I \mathrm{IBr}_{1}$, and $\mathrm{IIIBr}_{2}$ or $\mathrm{IIIBr}_{4}$ axillary; arms laterally in contact and firmly joined together at sides. Circular columnals wide, low, with large circular lumen.

REMARKS: In the original description of this genus, Kirk (1933) erected the type species and Syndetocrinus northropi; these have been synonymised (Webster 2003). A third species, Syndetocrinus schucherti (see Kirk 1933, p. 351) is a nomen nudum and is interpreted as a name discarded for the type species, but erroneously left in the typescript. Syndetocrinus dartae is also recorded from Bohemia; three other nominal species are known from Russia (Webster 2003; Webster and Webster, 2014, p. 2095).

RANGE: Silurian (Wenlock - Ludlow) of Canada, central 


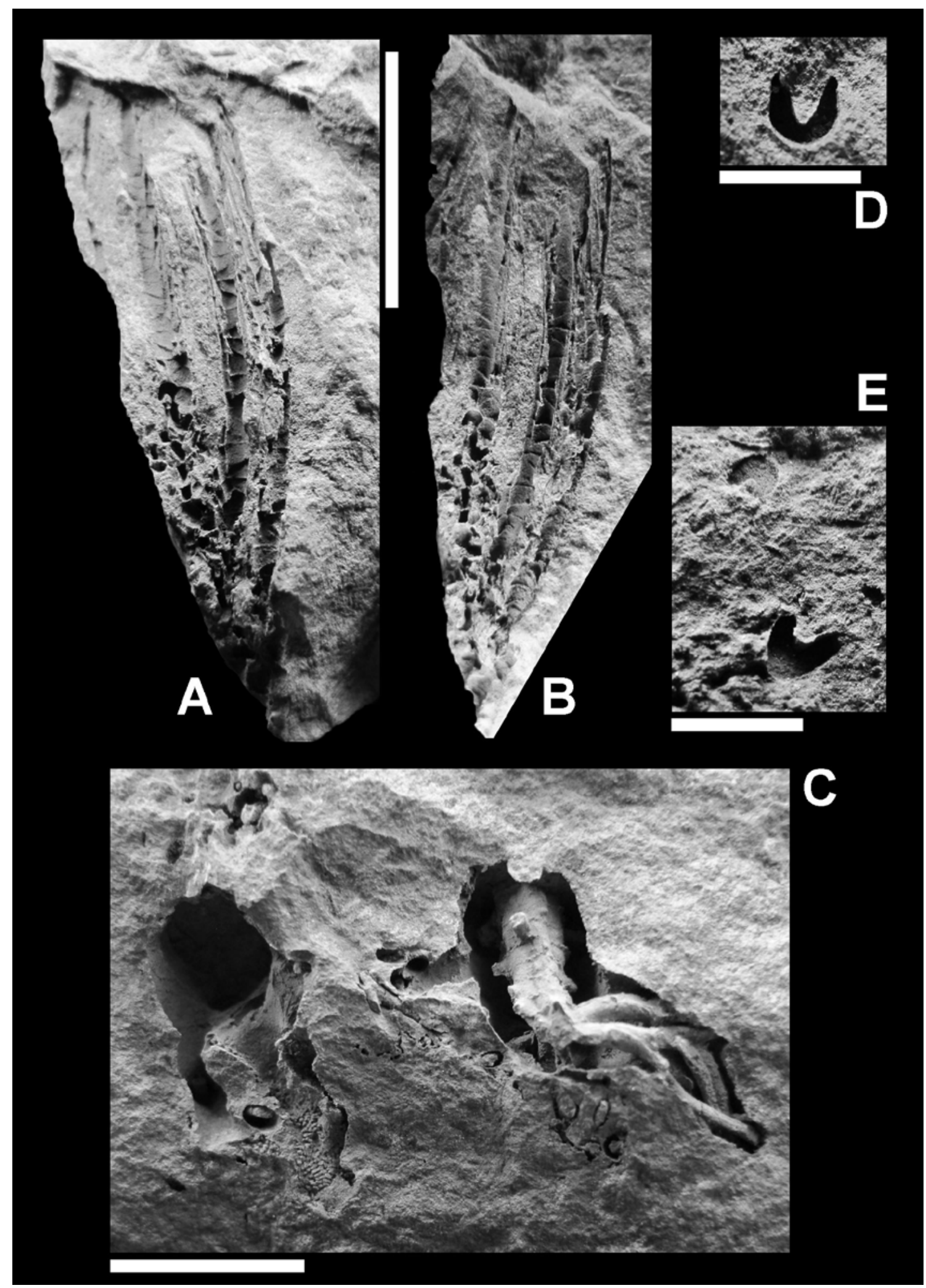

Figure 3. Crinoids from the Silurian of New Brunswick, New Brunswick Museum. (A, B) NBMG 2413/11, camerate crinoid arms gen. et sp. indet. Two views of pinnulate, biserial arms. Scale bar represents $10 \mathrm{~mm}$. (C) NBMG 10933, distal dendritic radicular attachments; both specimens are moldic. The attachment on the right is more complete, but that on the left is partly encrusted by bryozoans. Scale bar represents $10 \mathrm{~mm}$. (D) NBMG 10831, brachial. (E) NBMG 10808, two brachials. Specimens uncoated. Scale bars represent $5 \mathrm{~mm}$ unless stated otherwise. 
Europe and Russia (Webster and Webster 2014, p. 2095).

\section{Syndetocrinus dartae Kirk 1933}

(Figure 4)

MATERIAL: NBMG 17888 (nine pluricolumnals), 17889 (three pluricolumnals in cobble), 17890 (two pluricolumnals, one attachment structure), 18371 (pluricolumnals in cobble), 18372 (one specimen in section) and 18373 (one cobble with several pluricolumnals in section).

LOCALITIES AND HORIZONS: Specimens NBMG 17888 to 17890, Cap de l'Enfer, Port Daniel, Quebec; West Point Formation; Upper Silurian (uppermost Ludlow? to Pridolian). Specimens NBMG 18371 to 18373 , Port Daniel West, Quebec; Indian Point Formation; Upper Silurian (Pridolian) (Bourque et al. 2005, fig. 4, col. 4) (Fig. 1C).

DESCRIPTION: Preserved as pluricolumnals and attachment structures (Fig. 4). Pluricolumnals homeomorphic, cylindrical to conical, composed of low columnals with convex latera which may be overgrown by secondary calcite in the attachment structure. Lumen rounded pentagonal to pentalobate in section, moderately broad to broad (always at least $50 \%$ of columnal diameter; Figs. $4 \mathrm{~A}, \mathrm{~B}, \mathrm{D}$ ), may vary in diameter over about $30 \mathrm{~mm}$ of pluricolumnals or remain unaltered. Two to five irregular columns of radice scars are present in the dististele (Fig. 4E), regularly spaced with about $72^{\circ}$ between columns, may be flanged giving the column a pentastellate section, widening distally. Columnal may show division into inner and outer layers of calcite (Fig. 4D).

REMARKS: This is the only species of Syndetocrinus known from the Silurian succession of eastern Canada and the NBMG specimens have been 'lumped' therein. That they are crotalocrinitid pluricolumnals is undoubted; for example, compare Figure 4 herein with the type of Crotalocrinities, Crotalocrinities verucosus (Schlotheim 1820), and Pleuropteryx punctatus (Hisinger 1828) from the Early Silurian (Wenlock) of England (Donovan et al. 2010, pl. 17, fig. 2, pl. 18).

Incerti ordinis

Morphogenus Floricrinus (col.) Stukalina 1977

TYPE SPECIES: Floricrinus proteus Stukalina 1977, p. 152, pl. 31, fig. 5, from the Lower Devonian Sardzhal Horizon, Kazakh Horizon of Kazakhstan (Webster 2003).

OTHER NOMINAL SPECIES: Webster and Webster (2014, p. 2436-2437) noted a further five nominal species of Floricrinus (col.), to which has been added Floricrinus (col.) priscus (Goldfuss 1831 in Goldfuss 1826-1844) (Donovan 2012).
DIAGNOSIS: (After Donovan 2012, p. 117.) Crinoid columnal morphogenus with a small, central, pentagonal lumen; five more or less lobate, long areola petals, each corresponding to a side of the lumen; and a crenularium of radial crenulae that extend from the sides of the areola, with a chevron-like geometry between the petals and curving to be near-radial at the circumference of the articular facet.

REMARKS: The morphology of the areola petals of Devonian Floricrinus (col.) is reminiscent of Ordovician genera such as Iocrinus Hall (e.g., Donovan and Gale 1989, text-figs. 4B, D) or Ranunculocolumnus (col.) Donovan (e.g., Donovan 1995, text-figs. 53E, G, H). Columnals of comparable morphology are unknown from the Silurian, at least of the British Isles (Donovan 2012, p. 118). Floricrinus (col.) is broadly similar to these Ordovician taxa and also to Mesozoic columnals such as Pentacrinites Blumenbach (see Hess 2011, figs. 21i-k), but lacks cirrus scars. The specimens described herein (Fig. 5) are the oldest known Floricrinus (col.).

RANGE: Upper Silurian (Pridoli) of New Brunswick (herein); Lower Devonian of southwestern England (Donovan 2012); Lower to Middle Devonian of Russia and Kazakhstan (Webster and Webster 2014); Middle Devonian (Eifelian) of Germany, and Paleozoic of Estonia (Webster 2003; Donovan 2012, p. 117).

\section{Floricrinus (col.) sp.} (Figure 5)

MATERIAL: NBMG 9937, 10805, 10806, 10836, 10840, 10841, 10849, 10860 (more than six columnals), 10868, 10893, 10895. Preserved as natural molds; most specimens bear a single columnal.

LOCALITY AND HORIZON: All specimens from Cookson Island, New Brunswick; Upper Silurian, Ludlow to Pridoli or Pridoli, as indicated by the presence of Salopina submedia (see Calef and Hancock 1974; Lawson 1975; Pickerill 1976 for precise correlation) (Fig. 1D).

DESCRIPTION: Articular facet iocrinid-like (Figs. 4A$\mathrm{C}, \mathrm{E}-\mathrm{H})$. Rounded pentagonal in outline. Lumen central, small and pentagonal. Areola of five, finger-like to broader, slightly depressed petals extending from angles of lumen towards angles of columnal. Articulation symplectial, crenulae curving from circumference of areola petals to being perpendicular to circumference of articular facet, also extending from lumen. Crenulae numerous, fine and unbranched, commonly straight to slightly fanned between areola petals to radiating around tips of areola petals. NBMG 10840 and 10841 comprise external molds of 


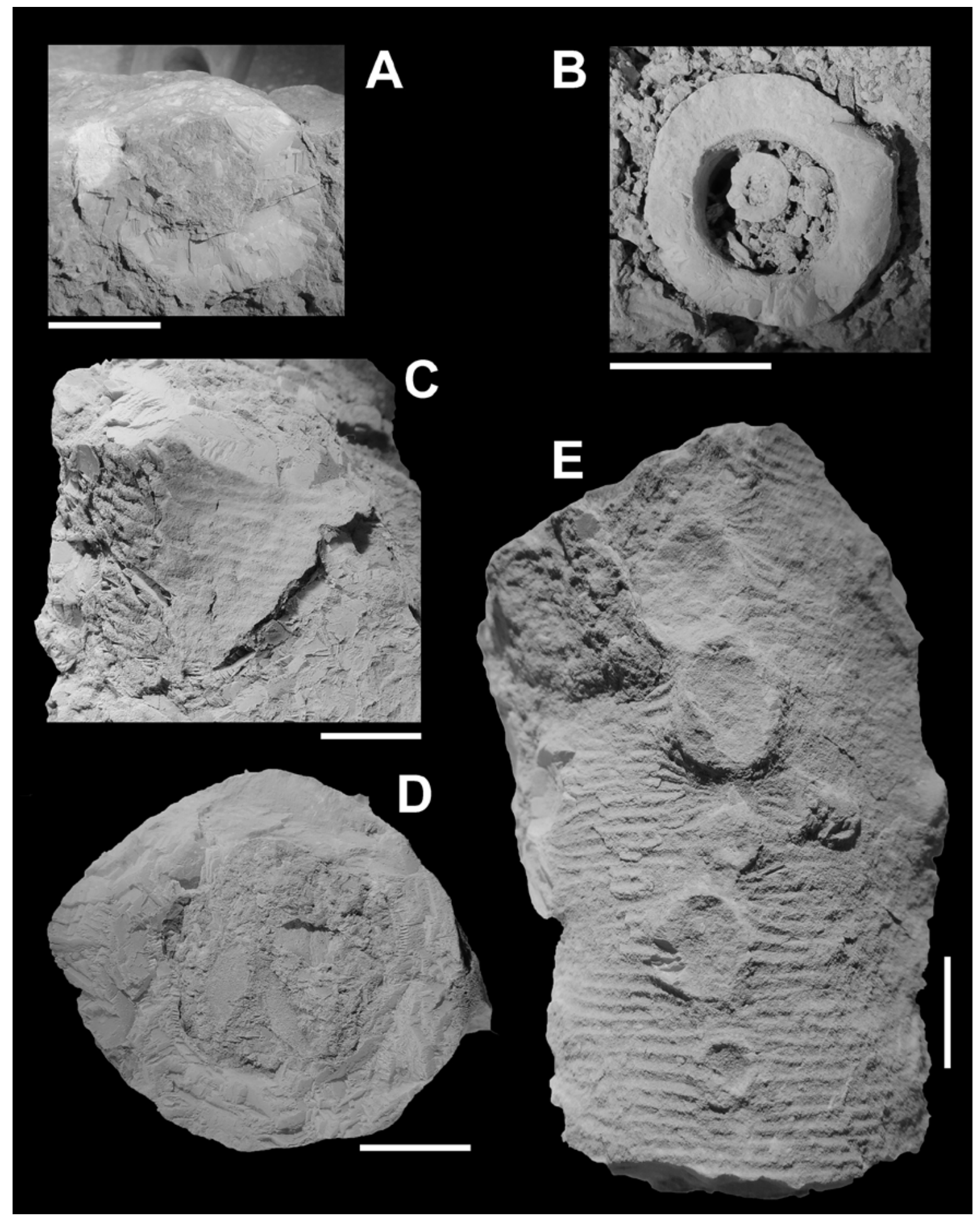

Figure 4. Syndetocrinus dartae Kirk 1933, from the Upper Silurian of the Gaspe Peninsula, Quebec. (A) NBMG 18373, transverse section of pluricolumnal. (B) NBMG 18371, transverse section of pluricolumnal. (C) NBMG 17890, lateral view of pluricolumnal. (D, E) NBMG 17888 (two different specimens). (D) Transverse view of pluricolumnal with faint traces of crenulae and thickening of columnal . (E) Attachment structure showing radice scars arranged in column; orientation uncertain, may be inverted. Specimens coated with ammonium chloride. Scale bars represent $10 \mathrm{~mm}$. 


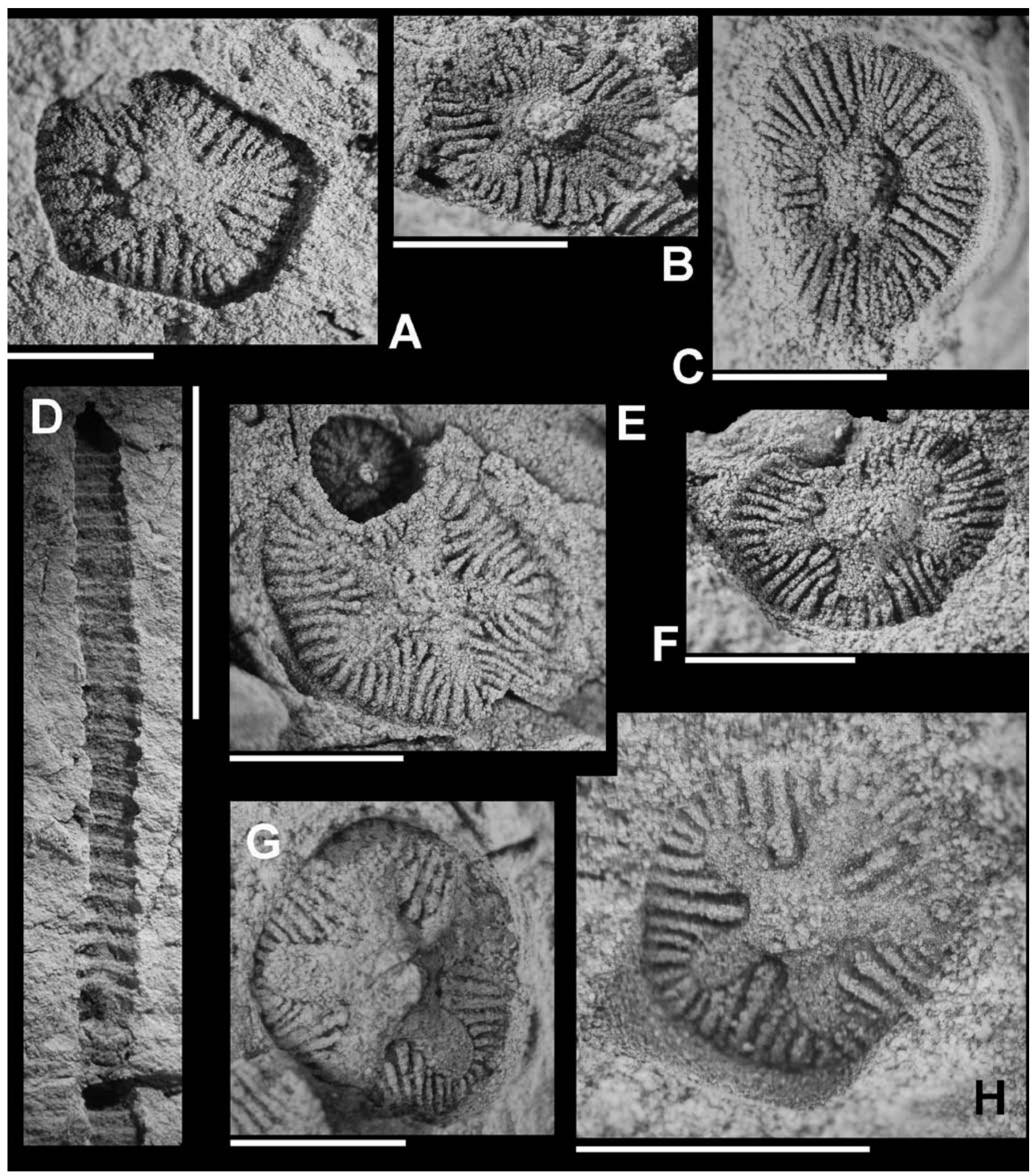

Figure 5. Floricrinus (col.) sp. from the Upper Silurian of Cookson Island, New Brunswick. All images show external molds of the articular facet except (D). (A) NBMG 10805. (B) NBMG 10849. (C) NBMG 10840. (D) NBMG 10841, external mold of long pluricolumnal showing obvious heteromorphy. Scale bar represents $10 \mathrm{~mm}$. (E) NBMG 9937. (F) NBMG 10836. (G) NBMG 10895. (H) NBMG 10893. Specimens coated. Scale bars represent $2 \mathrm{~mm}$ except (D). 
pluricolumnals, the latter $26.5 \mathrm{~mm}$ long (Fig. 5D). Latera unsculptured, gently convex. Column heteromorphic, $\mathrm{N} 1$, nodals about twice the height of low priminternodals.

REMARKS: The associated biota includes trilobites (Calymene antigonishensis) and brachiopods (Salopiae submedia, Leptaena sp. cf. L. depressa).

\section{Morphogenus Lanxocolumnus (col.) Donovan 1995}

TYPE SPECIES: Lanxocolumnus (col.) quinquelateralis Donovan 1995, p. 139, pl. 22, figs. 1-4, by original designation, from the Upper Ordovician [Katian (=Caradoc; Fortey et al. 2000, fig. 24), clingani Biozone; Mohibullah et al. 2014, textfig. 2] of the Craighead Limestone Formation, Craighead Inlier, Ardmillan Group, Strathclyde, southwestern Scotland.

OTHER SPECIES: Lanxocolumnus (col.) chaleurensis Donovan and Keighley 2015 (Silurian, Llandovery, Telychian of New Brunswick); Lanxocolumnus (col.) geoffnewalli (Fearnhead and Donovan 2007) (Silurian, Llandovery, Telychian of England); Lanxocolumnus (col.) spp. A-F in Donovan 1995 (Katian of southwestern Scotland); Lanxocolumnus (col.) sp. in Bouman and Donovan 2015 (Mississippian of England).

DIAGNOSIS: (After Donovan and Keighley 2015, p. 228.) Pentagonal to circular columnals with a pentagonal to circular (uncommonly elliptical) articular facet. Lumen central, opposed, either pentagonal, pentalobate or pentastellate in outline. Articulation is symplectial, with fine crenulae developed on the articular facet and more massive crenulae(?) uncommonly occurring on the epifacet of nodals at the internodal angles. Columnal and lumen angles rounded. Column heteromorphic. Nodals and high order internodals with more or less swollen epifacets.

REMARKS: Unpublished research indicates that the type, L. (col.) quinquelateralis, may be a junior synonym of a species of the diplobathrid camerate genus Diabolocrinus Wachsmuth and Springer 1897, from the Craighead Inlier, southwestern Scotland (personal observations of SKD and Neil D.L. Clark, research in progress).

RANGE: Upper Ordovician (Katian) of southwestern Scotland; Lower Silurian (Llandovery, Telychian) of New Brunswick, and Shropshire, England; less certainly, Lower Carboniferous (Mississippian, Brigantian $\left(\mathrm{D}_{2}\right)$, Visean) of Derbyshire, England (Donovan 1995; Fearnhead and Donovan 2007 (as Cyclocyclicus); Donovan and Keighley 2015; Bouman and Donovan 2015).

\author{
Lanxocolumnus (col.) sp. cf. L. chaleurensis \\ Donovan and Keighley 2015
}

(Figure 6)

MATERIAL: Columnals and pluricolumnals, NBMG $2413 / 1,3,4,5,6,7,8,9,10,12,17891-17894$.

LOCALITY AND HORIZON: NBMG 2413 are from "McIntyre's, Nerepis, New Brunswick, Silurian" (specimen label); Jones Creek Formation, Mascarene Group, Early Silurian (MacKenzie 1964) (Fig. 1B). NBMG 17891-17894 are from Jones Creek, Kings County, New Brunswick; Jones Creek Formation. [The type locality of $L$. (col.) chaleurensis sensu stricto is a coastal exposure at Quinn Point, about 7 $\mathrm{km}$ west of Belledune, northern New Brunswick. Vertical limestones of the Limestone Point Formation, Quinn Point Group (see above). Silurian, Llandovery, Telychian.]

DESCRIPTION: Moderately large, circular columnals with a particularly small, central, pentagonal(?) lumen; perilumen narrow, rounded in outline; areola circular, depressed, planar; articulation symplectial, moderately broad, extending to circumference of articular facet; crenulae fine, branched. Areola narrow to broad, the latter reducing the width of the crenularium.

Pluricolumnal heteromorphic, perhaps N212. Nodals and priminternodals both with convex latera, but slightly asymmetric, with a low ridge at one end; at least one external mold with nodes on nodal latera; $2 \mathrm{IN}$ with planar latera.

REMARKS: These specimens have been left in open nomenclature, in part because of the difficulty of comparing specimens preserved as molds (Fig. 6) with a taxon otherwise known from calcitic preservation (Donovan and Keighley 2015). Further, the range of morphologies shown by the Jones Creek Formation specimens is greater than for the type series and epifacets are relatively weakly developed.

Where present, these specimens are preserved in finegrained sandstone. This contrasts with the coarser-grained sandstone in which Lanxocolumnus (col.) geoffnewalli (Fearnhead and Donovan 2007) from the Silurian of Shropshire, England, is commonly preserved; finer details are thus preserved in the New Brunswick specimens.

\section{distal dendritic radicular attachment}

\section{(Figure 3C)}

MATERIAL: A single specimen, NBMG 10933.

LOCALITY AND HORIZON: "Cookson Island, N.B. Silurian" (specimen label). Upper Silurian, Ludlow to Pridoli or Pridoli, as indicated by the presence of 


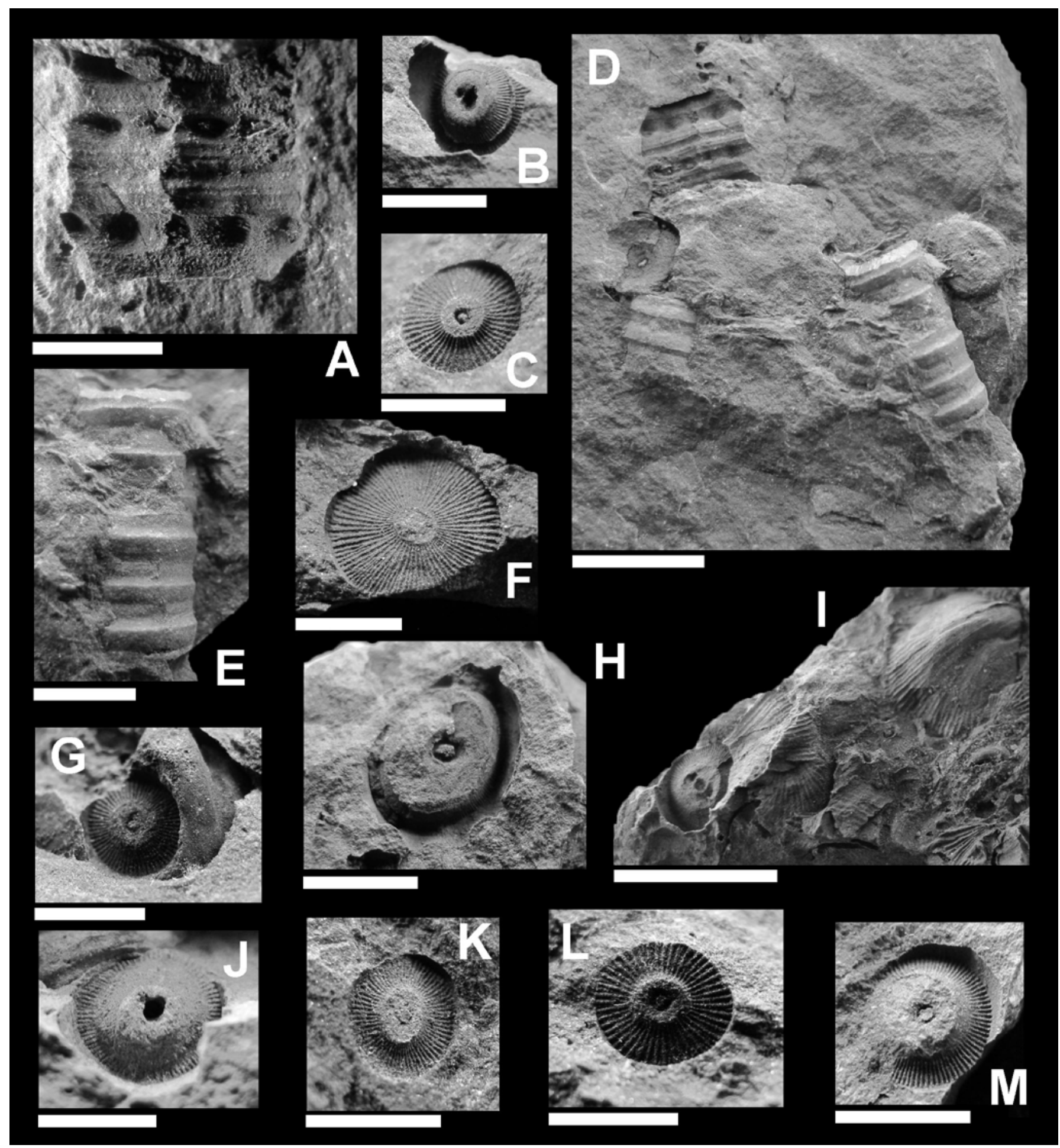

Figure 6. Lanxocolumnus (col.) sp. cf. L. chaleurensis Donovan and Keighley, 2015, from the Early Silurian Jones Creek Formation, Nerepis, New Brunswick. All external molds except (D, E). (A, D, E, H) NBMG 2413/1. (A) Moldic pluricolumnal, inverted compared with view in (D, upper left). (D) Bedding plane view of pluricolumnals; note absence of broad epifacets. Scale bar represents $10 \mathrm{~mm}$. (E) Pluricolumnal; lower right in (D). (H) Articular facet. (B) NBMG 2413/12, oblique view of facet and latus. (C) NBMG 2413/5, articular facet of low order internodal lacking epifacet. (F) NBMG 2413/7, articular facet of presumed proxistele; otherwise may represent another taxon. (G) NBMG 2413/6, articular facet. (I) NBMG 17893, bedding plane view of crinoids and brachiopods forming a shelly hash. (J) NBMG 17894, articular facet. (K) NBMG 2413/8, articular facet. (L) NBMG 2413/9, articular facet. (M) NBMG 2413/10, articular facet. Specimens uncoated. Scale bars represent $5 \mathrm{~mm}$ unless stated otherwise. 
Salopina submedia (see above) (Fig. 1D).

DESCRIPTION: Distal dendritic radicular attachments (Brett 1981) preserved side-by-side (Fig. 3C), the better preserved specimen including a mold of the axial canals of the column and longer radices. Axial canal pentagonal in section, tapering distally. Column homeomorphic(?), canals of radices arising from all columnals (= nodals), from both the angles and the centers of the faces of the axial canal. Articulation of column symplectial at axial canal. Radice articulation unknown; radice canals circular in section, sinuous, dichotomously branched several times.

REMARKS: The label states "Anthozoa - Rugosa", but these are very obviously crinoid attachment structures. For structures. For example, compare with Donovan (1986, pl. 4, figs 7, 8; and, particularly, 1995, pl. 26, fig. 5).

\section{brachials}

(Figures 3D, E)

\section{MATERIAL: NBMG 10808, 10831.}

LOCALITY AND HORIZON: "Cookson Island, N.B. Silurian” (specimen label). Upper Silurian, Ludlow to Pridoli or Pridoli, as indicated by the presence of Salopina submedia (see above) (Fig. 1D).

DESCRIPTION: Three external molds of uniserial crinoid brachial ossicles. NBMG 10831 (Fig. 3D) regular U-shaped in outline, slightly in-turned adjacent to oral surface. Adoral groove deep, V-shaped. Articular facet unsculptured. One brachial on NBMG 10808 is similar (Fig. 3E, lower), apart from the development of short, straight facets on adoral surface, adjacent to and sloping away from adoral groove. A second, conspecific brachial on this rock specimen has a shallower adoral groove and more U-shaped (Fig. 3E, upper).

REMARKS: There is little that can be confidently determined from these specimens. They may represent three separate species or three regions of the arms of one species.

\section{DISCUSSION}

In our introduction we stated that "... the crinoids of [the Silurian of New Brunswick] remain poorly known." Although still true, our determinations and descriptions add a little more flesh to this skeleton (Table 1).

Despite the extensive outcrop of Silurian rocks in New Brunswick (Fig. 1), crinoids have not been commonly reported. We suggest that this is due to two principal reasons, one intrinsic to the fossil record and the other extrinsic, related to methodology. The intrinsic factor is preservation, which is commonly poor (Figs 3, 5, and 6); specimens are commonly moldic and more or less disarticulated. Contrast this with the British Isles, where Silurian outcrops from both sides of the (closing) Iapetus Ocean are present. The British succession has perhaps six notable Silurian localities that have produced multiple specimens of well-preserved crinoids (Donovan et al. 2012b), most notably the Wenlock (Lower Silurian) around Dudley, West Midlands, which has yielded about 70 nominal crinoid taxa (Donovan et al. 2012a, table 8). These Lagerstätte are fossil mother-lodes that attract active collectors and lead to a rich literature on crinoid paleontology. In contrast, New Brunswick has no recognized crinoid Lagerstätte in Silurian strata.

This leads to the extrinsic factor: styles of collecting or, more correctly, the failure to collect. Some fossil groups, such as crinoid columnals and bryozoans, are not popular with collectors, especially when they show moldic preservation. The crinoids that are described herein, presumed to be typical of the Silurian of New Brunswick, mainly occur as columnals, pluricolumnals and brachials; these are small and nondescript. The only crinoid attachment structure was collected under the mistaken belief that it was a coral. Only an unusual columnal morphology, such as the distinctive articular facets of Floricrinus (col.) sp. (Figs. 5A-C, E-H), is likely to catch the eye of a collector. Most columnals are not so attractive and therefore are likely not to be collected.

The crinoids of the Silurian of New Brunswick are thus better known from our study, yet remain incompletely described. The few species that are documented herein represent taxa that are typical of the Silurian. Their discovery is unsurprising; but there remains a dearth of species and specimens. We consider this situation to be an artifact, which only furtheraccumulation by informed collectors can remedy.

In conclusion, the fossil record of crinoids from the Silurian of New Brunswick appears depauperate, but this most likely reflects the poor preservation of the specimens (commonly disarticulated and moldic) and the lack of interest shown in them by collectors. The only likely 'cures' for these problems would be either discovery of a crinoid Lagerstätte, which would be attractive to collectors, or a focused campaign of collecting of disarticulated material from multiple outcrops.

\section{ACKNOWLEDGEMENTS}

S.K.D. gratefully acknowledges the award of a G.F. Matthew Research Grant for 2013 by the New Brunswick Museum, which facilitated this research in May 2014. R.F.M. thanks M. Hébert and M. Stimson (New Brunswick Museum), and W.D. Boyce (Department of Natural Resources, Geological Survey, Newfoundland and Labrador) for assistance organizing and photographing collections. 
Table 1. Silurian crinoids of New Brunswick (Donovan and Miller 2014; Donovan and Keighley 2015; herein). Species are either morphotaxa or listed in open nomenclature or both. This suggests that fossil material is mainly disarticulated ossicles and incomplete, but articulated, skeletal fragments that are difficult to classify within the Linnean system, lacking the evidence provided by cups and crowns. Stage occurrence is indicated where known.

\section{Upper Silurian}

Scyphocrinites sp.

Floricrinus (col.) sp.

distal dendritic radicular attachment

brachials
Pridoli

Ludlow or Pridoli

Ludlow or Pridoli

Ludlow or Pridoli

\section{Lower Silurian}
Lanxocolumnus (col.) chaleurensis Donovan and Keighley
Llandovery, Telychian
L . (col.) sp. cf. L. chaleurensis Donovan and Keighley
camerate crinoid arms gen. et sp. indet.

We thank our reviewers, D. G. Keighley (University of New Brunswick, Fredericton) and G. D. Webster (Washington State University, Pullman), for their constructive comments; special thanks to the former for redrawing and improving Figure 1. We thank Robert Fensome for his careful editorial comments of this manuscript.

\section{REFERENCES}

Ausich, W.I. and Copper, P. 2010. The Crinoidea of Anticosti Island, Québec (Late Ordovician to Early Silurian). Palaeontographica Canadiana, 29, $157 \mathrm{p}$.

Ausich, W.I. and Deline, B. 2012. Macroevolutionary transition in crinoids following the late Ordovician extinction event (Ordovician to early Silurian). Palaeogeography, Palaeoclimatology, Palaeoecology, 361/362, pp. 38-48. http://dx.doi.org/10.1016/j.palaeo. 2012.07.022

Bassler, R.S. 1938. Pelmatozoa Palaeozoica. In Fossilium catalogus, I: Animalia. Part 83. Edited by W. Quenstedt. W. Junk, s'Gravenhage, $194 \mathrm{pp}$.

Bengtson, P. 1988. Open nomenclature. Palaeontology, 31, pp. 223-227.

Bouman, R.W. and Donovan, S.K. 2015. Biodiversity of Mississippian (Lower Carboniferous) crinoids from Bradford Dale, Derbyshire, U.K. Proceedings of the Yorkshire Geological Society, 60, pp. 293-302.

Bourque, P.-A., Desbiens, S., and Gensel, P.G. 2005. Silurian-Devonian Biota and Paleoenvironments of
Gaspé Peninsula and northern New Brunswick. NAPC 2005, Halifax, Nova Scotia. Guidebook, xiv+143 p.

Brenchley, P.J. 1989. The Late Ordovician extinction. In Mass extinctions: processes and evidence. Edited by S.K. Donovan. Belhaven Press, London, pp. 104-132.

Brett, C.E. 1981. Terminology and functional morphology of attachment structures in pelmatozoan echinoderms. Lethaia, 14, pp. 343-370. http://dx.doi. org/10.1111/j.1502-3931.1981.tb01110.x

Calef, C.E. and Hancock, N.J. 1974. Wenlock and Ludlow marine communities in Wales and the Welsh Borderland. Palaeontology, 17, pp. 779-810.

Donovan, S.K. 1986. Pelmatozoan columnals from the Ordovician of the British Isles. Part 1. Monograph of the Palaeontographical Society, London, 138 (no. 568), pp. $1-68$.

Donovan, S.K. 1988. The British Ordovician crinoid fauna. Lethaia, 21, p. 424. http://dx.doi.org/10.1111/j.1502-3931. 1988.tb01773.

Donovan, S.K. 1994. The late Ordovician extinction of the crinoids in Britain. National Geographic Research and Exploration, 10, pp. 72-79.

Donovan, S.K. 1995. Pelmatozoan columnals from the Ordovician of the British Isles. Part 3. Monograph of the Palaeontographical Society, London, 149 (no. 597), pp. 115-193.

Donovan, S.K. 2012. Notes on Lower Devonian crinoids in the collections of the British Geological Survey, Keyworth. Proceedings of the Yorkshire Geological Society, 59, pp. 115-120. http://dx.doi.org/10.1144/pygs2012-318 
Donovan, S.K. and Gale, A.S. 1989. Iocrinus in the Ordovician of England and Wales. Palaeontology, 32, pp. 313-323.

Donovan, S.K. and Keighley, D.G. 2015. A 'British' Silurian crinoid from Quinn Point, New Brunswick, eastern Canada. Proceedings of the Geologists' Association, 126, pp. 226-231.

Donovan, S.K. and Keighley, D.G. 2016. Fossil crinoids from the basal West Point Formation (Silurian), southeast Gaspé, Québec, eastern Canada. Atlantic Geology, 52, pp. 211-222. http://dx.doi.org/10.4138/atlgeol.2016.009

Donovan, S.K. and Miller, R.F. 2014. The camerate crinoid Scyphocrinites Zenker in the Upper Silurian or Lower Devonian of New Brunswick, Canada. Atlantic Geology, 50, pp. 290-296. http://dx.doi.org/10.4138/ atlgeol.2014.014

Donovan, S.K. and Pickerill, R.K. 1995. A camerate crinoid from the Upper Silurian (Ludlow) Moydart Formation of Nova Scotia, Canada. Atlantic Geology, 31, pp. 81-86. http://dx.doi.org/10.4138/2099

Donovan, S.K., Lewis, D.N., Fearnhead, F.E., and Widdison, R.E. 2009. The British Silurian Crinoidea. Part 1, introduction and Disparida. Monograph of the Palaeontographical Society, London, 163 (632), pp. 1-45.

Donovan, S.K., Widdison, R.E., Lewis, D.N., and Fearnhead, F.E. 2010. The British Silurian Crinoidea. Part 2, addendum to Part 1 and Cladida. Monograph of the Palaeontographical Society, London, 164 (635), pp. 47133.

Donovan, S.K., Widdison, R.E., Lewis, D.N., and Fearnhead, F.E. 2012a. The British Silurian Crinoidea. Part 3, addendum to parts 1 and 2, Camerata and columnals. Monograph of the Palaeontographical Society, London, 166 (638), pp. 135-259.

Donovan, S.K., Lewis, D.N., and Fearnhead, F.E. 2012b. Classic localities explained 10: Crinoid localities of the Silurian of the British Isles. Geology Today, 28, pp. 230237. http://dx.doi.org/10.1111/j.1365-2451.2012.00856.x

Donovan, S.K., Keighley, D.G., Miller, R.F., and Wilson, R.A. 2015. Silurian crinoids from northern New Brunswick, eastern Canada. Atlantic Geology, 51, p. 114. http:// dx.doi.org/10.4138/atlgeol.2015.005

Eckert, J. 1988. Late Ordovician extinction of North American and British crinoids. Lethaia, 21, pp. 147-167. http://dx.doi.org/10.1111/j.1502-3931.1988.tb00805.x

Fearnhead, F.E. and Donovan, S.K. 2007. A robust crinoid from the Llandovery (Lower Silurian) of Norbury, Shropshire: systematics, palaeoecology and taphonomy. Proceedings of the Geologists' Association, 118, pp. 339345.

Fortey, R.A., Harper, D.A.T., Ingham, J.K., Owen, A.W., Parkes, M.A., Rushton, A.W.A., and Woodcock, N.H. 2000. A revised correlation of Ordovician rocks in the British Isles. Geological Society, Special Report, 24, 83 p.
Goldfuss, A. 1826-1844. Petrefacta germaniae, tam ea, quae in museo universitatis regiae Borussicae Friderciae Wilhelmiae Rhenanae, serventur, quam alia quaecunque in museis Hoening husiano Muensteriano aliisque, extant, iconibus et descriptions illustrata. Abbildungen und Beschreibungen der petrefacten Deustchlands und der Angränzenden ?Länder, unter mitwirkung des herrn grafen Georg zu Münster, Herausgegeben von August Goldfuss. Volume 1, division secunda. Radiariorum reliquiae. Pp. 115-221. Arnz and Co., Dusseldorf. [Not seen.]

Guensburg, T.E. 2010. Alphacrinus new genus and origin of the disparid clade. Journal of Paleontology, 84, pp. 12091216. http://dx.doi.org/10.1666/10-030.1

Guensburg, T.E. and Sprinkle, J. 2003. The oldest known crinoids (Early Ordovician, Utah) and a new crinoid plate homology system. Bulletins of American Paleontology, $364,43 \mathrm{p}$.

Haude, R. 1992. Scyphocrinoiden, die Bojen-Seelilien im hohen Silur-tiefen Devon. Paleontographica Abteilung A, Palaeozoologie und Stratigraphie, 222, pp. 141-187.

Hess, H. 2011. Isocrinida. In Treatise on invertebrate paleontology. Part T. Echinodermata 2(3, revised). By H. Hess and C.G. Messing. University of Kansas Paleontological Institute, Lawrence, pp. 42-69.

Hess, H. and Ausich, W.I. 1999. Introduction. In Fossil crinoids. By H. Hess, W.I. Ausich, C.E. Brett and M.J. Simms. Cambridge University Press, Cambridge, pp. xiii$\mathrm{xv}$.

Hisinger, W. 1828. Anteckningar i physik och geognosie und resor uti Sverige och Norrige. Volume 4. Sjunde Haftet, Stockholm, xii+260 p.

Jaekel, O. 1918. Phylogenie und System der Pelmatozoen. Paläeontologisches Zeitschrift, 3 (1), pp. 1-128. http:// dx.doi.org/10.1007/BF03190413

Kammer, T.W. and Ausich, W.I. 2006. The "Age of Crinoids": a Mississippian biodiversity spike coincident with widespread carbonate ramps. Palaios, 21, pp. 238-248. http://dx.doi.org/10.2110/palo.2004.p04-47

Kirk, E. 1933. Syndetocrinus, a new crinoid genus from the Silurian of Canada. American Journal of Science, 26, pp. 344-354. http://dx.doi.org/10.2475/ajs.s5-26.153.344

Lawson, J.E. 1975. Ludlow benthonic assemblages. Palaeontology, 18, pp. 509-525.

MacKenzie, G.S. 1964. Geology of Hampstead, New Brunswick. URL <http://dnr-mrn.gnb.ca/Lexicon/ Lexicon/Lexicon_Print.aspx> May, 2014.

Miller, J.S. 1821. A natural history of the Crinoidea or lilyshaped animals, with observation on the genera Asteria, Euryale, Comatula and Marsupites. C. Frost, Bristol, 150 p.

Mohibulla, M., Williams, M. and Zalasiewicz, J. 2014. Late Ordovician ostracods of the Girvan district, south-west Scotland. Monograph of the Palaeontographical Society, London, 167 (640), 40 p. [Cover date 2013, publication 
date 2014.]

Moore, R.C. and Laudon, L.R. 1943. Evolution and classification of Paleozoic crinoids. Geological Society of America Special Paper, 46, 153 p. http://dx.doi. org/10.1130/spe46-p1

Moore, R.C., Jeffords, R.M., and Miller, T.H. 1968. Morphological features of crinoid columns. University of Kansas Paleontological Contributions, Echinodermata Article 8, pp. 1-30.

Moore, R.C. with additions by Ubaghs, G., Rasmussen, H.W., Breimer, A., and Lane, N.G. 1978a. Glossary of crinoid morphological terms. In Treatise on invertebrate paleontology. Part T. Echinodermata 2(1). Edited by R.C. Moore and C. Teichert. Geological Society of America and University of Kansas Press, Boulder and Lawrence, pp. T229, T231, T233-T242. (Cited as Moore et al. 1978a).

Moore, R.C., Lane, N.G. and Strimple, H.L. 1978 b. Order Cladida Moore \& Laudon, 1943. In Treatise on invertebrate paleontology. Part T. Echinodermata 2(2). Edited by R.C. Moore and C. Teichert. Geological Society of America and University of Kansas Press, Boulder and Lawrence, pp. T578-T759.

Pickerill, R.K. 1976. Significance of a new fossil locality containing a Salopina community in the Wanweig Formation (Silurian - uppermost Ludlow/Pridoli). Canadian Journal of Earth Sciences, 13, pp. 1328-1331. http://dx.doi.org/10.1139/e76-134

Schlotheim, E.F. von. 1820. Die Petrefactenkunde auf ihrem jetzigen Standpunkte durch die Beschreibung einer Sammlung versteinerter und fossiler Überretse des Theirund Pflanzenreichs der Vorwelt erläutert. Beckersche Buchhandlung, Gotha, 437 p.

Stukalina, G.A. 1977. Novie morskie lilii devona Urala, Kazakhstana i Dalnego Vostoka V kn. Novie vidi drevnikh rastenii i bespozvonochnikh SSSR [New Devonian crinoids from the Urals, Kazakhstan and the Far East]. In [New species of ancient plants and invertebrates of the
USSR, No. 4]. Edited by G.A. Stukalina. Paleontological Institute, Akademie Nauk SSSR, pp. 151-159. [In Russian; not seen.]

Ubaghs, G. 1978a. Skeletal morphology of fossil crinoids. In Treatise on invertebrate paleontology. Part $\mathrm{T}$. Echinodermata 2(1). Edited by R.C. Moore and C. Teichert. Geological Society of America and University of Kansas Press, Boulder and Lawrence, pp. T58-T216.

Ubaghs, G. 1978b. Camerata. In Treatise on invertebrate paleontology. Part T. Echinodermata 2(1). Edited by R.C. Moore and C. Teichert. Geological Society of America and University of Kansas Press, Boulder and Lawrence, pp. T408-T519.

Wachsmuth, C. and Springer, F. 1885. Revision of the Palaeocrinoidea, part III, section 1. Discussion of the classification and relations of the brachiate crinoids, and conclusion of the generic descriptions. Proceedings of the Academy of Natural Sciences of Philadelphia for 1885, pp. 223-364.

Wachsmuth, C. and Springer, F. 1897. The North American Crinoidea Camerata. Memoirs of the Harvard College Museum of Comparative Zoology, 20-21, 897 p.

Webster, G.D. 1974. Crinoid pluricolumnal noditaxis patterns. Journal of Paleontology, 48, pp. 1283-1288.

Webster, G.D. 2003. Bibliography and index of Paleozoic crinoids, coronates, and hemistreptocrinoids 1758-1999. Geological Society of America Special Paper, 363. URL $<$ http://crinoid.gsajournals.org/crinoidmod> Currently offline.

Webster, G.D. and Webster, D.W. 2014. Bibliography and Index of Palaeozoic crinoids: Paleozoic crinoids, coronates, and hemistreptocrinoids, 1758-2012. viii+2694 pp. URL $<$ http://crinoids.azurewebsites.net/> March, 2016.

Zenker, J.C. 1833. Organische Reste (Petrefacten) aus der Altenburger Braunkohlen-Formation etc. Beiträge zur Naturgeschite Urwelt, Jena, viii+67 p. [Not seen.]

Editorial responsibility: Robert A. Fensome 